\title{
Bile Duct Papillary Neoplasm
}

National Cancer Institute

\section{Source}

National Cancer Institute. Bile Duct Papillary Neoplasm. NCI Thesaurus. Code C6881.

A non-invasive, papillary epithelial neoplasm that arises from the epithelium of the intrahepatic or extrahepatic bile ducts. 